\title{
A RELATIONSHIP STUDY ON MARKETING STRATEGY MANAGEMENT TOWARDS CUSTOMER RELATIONSHIP MANAGEMENT AND PERCEIVED VALUE
}

\author{
Qiong $\mathrm{YANG}^{1}-$ Zen-hua $\mathrm{HU}^{2}$ \\ ${ }^{1}$ Business School of Central South University, Building 2-1603 of Ceng Shang Guan Di, No. 77 \\ Puyuan Shui Zhu Street, Tianxin District, Changsha, Hunan, 410083, China. \\ Email:609204356@qq.com (corresponding author) \\ ${ }^{2}$ Hunan Vocational College of Science \& Technology, Hunan, 410004, China
}

With the promotion of economic liberalization and internationalization, consumer demands have become complex and diversified. Businesses have to actively promote themselves and bring forth new marketing tactics to attract buying and cope with fierce competition so as to enhance the global competitiveness and implement the idea of sustainable operation. This study aims to investigate the relationship between marketing strategy management, customer relationship management, and perceived value.

Aiming at Suzhou Industrial Park, the executives and employees of the manufacturers are distributed 500 copies of questionnaire for this study, and 367 valid copies are retrieved, with the retrieval rate $73 \%$. The research results show the significant correlations between 1 . marketing strategy management and customer relationship management, 2. customer relationship management and perceived value, and 3. marketing strategy management and perceived value. Aiming at above results, suggestions are proposed to create better organizational performance for a business.

Keywords: marketing strategy management, customer relationship management, perceived value, customer acquisition, physical evidence

\section{INTRODUCTION}

Industrial competitiveness is currently in the globally perfervid era due to the promotion of economic liberalization and internationalization, resulting in impact on the businesses in the industries. The integration of resource planning and the upstream-downstream relationship in a business relies on the construction of organizational culture. Effectively applying marketing strategy management and customer relationship management (CRM) to enhance the industrial competitive- 
ness and create excellent organizational performance has become a popular topic in academic and industrial circles. With the changes of domestic economic structure and lifestyles in past years, consumer demands have become complicated and diversified. A business has to actively enhance itself, constantly promote the marketing tactics, and attract buying to cope with the fierce competition. However, high costs are also requested. Thoroughly mastering and satisfying consumer demands therefore become a key in business growth.

Enterprise managers constantly investigate to apply organizational cultural characteristics to the marketing strategy management and satisfy customer demands and expectation through marketing strategy development in order to acquire the potential business opportunities and enhance business competitiveness. Quality customer services are applied to maintain the favorable customer relationship, and the most suitable customers are offered products or services at the best time and best places with the maximum benefits and the minimum risks so as to create organizational performance ( $\mathrm{Xu}$ and Shieh 2014). Perceived value has been commonly regarded as a key factor in a consumer purchasing or using a product. A business provides customer with perceived value through products and services to enhance the repurchase intention and measures the perceived quality and perceived value of the paid price so that a manager could further understand customer demands. Current attitudes are usually a good predictor of repurchase; more importantly, perceived value, as the key factor in maintaining the competitive advantages of a business, could better measure consumer evaluation of services than service quality does. The relationship and the effects therefore are discussed in this study.

\section{LITERATURE REVIEW}

\subsection{Marketing strategy management}

Graa and Dani-el Kebir (2012) regarded marketing strategy management as the marketing logic for institutional organizations achieving the marketing plans, including specific strategies towards target markets, orientation, marketing mix, and marketing expenditure level. Marketing strategies should be able to point out the target market segmentation, which appears distinctly on demands \& desire, responses to marketing, and presents distinct profitability. A company could smartly find out the best service segmentation from the aspect of competition and formulate marketing strategies based on such selected target segmentation. The management echelon has to propose outlines of the marketing mix like new products, personnel sales, advertisement, promotion, price, and place for specific 
strategies. The management echelon should be able to explain how such strategies respond to the threats, opportunities, and problems in a plan. Klaus and Maklan (2012) defined Marketing Mix as the strategic marketing tool controlled by a company, containing product, price, place, and promotion, i.e. the marketing $4 \mathrm{P}$, to produce the responses of the target market. Product was the product and service mix for the target market; price was the amount paid by a customer to acquire a product; place covered the company activities which allowed the products being contacted by target customers; and promotion referred to the activities through which a company conveyed product value to the target customers and persuaded the purchase.

Based on 4P proposed, López-Gamero et al. (2011) proposed the 7P marketing strategy management mix, in which participant, process, and physical evidence were added to the past 4P (product, price, place, and promotion).

(1) Participant. Excellent personnel, including the proper skills and service enthusiasm, could stabilize the service quality. Employee training and control could have a business provide stable and reliable service quality. (2) Process. Being the mechanism and procedure to deliver to the customers, a business has to satisfy proper customer demands and timely deliver to customers in order to build customer satisfaction. (3) Physical evidence. The intangible service characteristic has a consumer not being able to understand the service situation and content in advance. A consumer often judges the service quality by the manner of the service place, novel equipment, and personnel enthusiasm. In this case, abstract and intangible services require physical evidence for consumers trusting the service provider.

\subsection{Customer relationship management}

Ayodele and Olorunsola (2012) indicated that customer relationship management was the mutual support through software and relevant technologies to achieve the automated management, aiming at sales, marketing, customer service and support, and to improve the business process. Chiu et al. (2011) pointed out customer relationship management as the combination of business process and technologies to understand customers from multiple dimensions and differentiate the products and services of a business. Green and Peloza (2011) regarded customer relationship management as understanding and influencing customer behaviors through meaningful communications to increase new customers, prevent the loss of existing customers, promote customer loyalty, and enhance customer profitability as well as all activities which could change random customers into loyal customers through satisfaction or exceeding the demands to generate repurchase 
behaviors. Lee and Jang (2011) pointed out customer relationship management as the broad process and information technology to manage the relationship among potential and existing customers and business partners through marketing, sales, and services. Ogunnaike et al. (2012) indicated that customer relationship management, as an information system, could assist an organization in realizing the actual customer needs. Tseng (2011) referred customer relationship to a business establishing long-term, satisfactory, reliable, and highly committed partner relationship with the customers through the combination of economy, technology, information, and society; and, favorable customer relationship could be presented through customer satisfaction, customer retention, customer churn rate, customer loyalty, and customer value. Klaus and Maklan (2012) regarded customer relationship management as a commercial model and strategic application; a business actively deepened the relationship with customers to master the customer information and formulate distinct strategic application with such information to satisfy different customer demands. Graa and Dani-el Kebir (2012) mentioned that customer relationship management needed to understand customer demands, provide personalized services, satisfy customer demands, and create favorable value and interactive relationship. A business has to stress on the customer interaction and service, constantly enhance the customer service quality with various innovative products and services for the customer relationship management. For the sustainable management, establishing permanent and close relationship with customers to create win-win situation has been concerned for years.

Referring to Amila and Aruna (2012), the customer relationship management performance is divided into the following dimensions.

(1) Customer acquisition. By integrating data from independent sources to analyze the purchase behaviors of new customers and establish the preference model, the most possibly purchased products could be confirmed, and the time when a customer might contact with the company and the communication approach could be realized. (2) Customer reinforcement. A business could solidify the customer relationship and further create more profits by ensuring the customer segmentation with the best profitability, discovering the most possibly purchased products, and effectively applying cross-selling and up-selling. (3) Customer bonding: By applying the purchase place where a customer prefers through Propensity Model to reduce the customer loss, the lifelong value of a customer could be acquired through the purchase behaviors in the life cycle. 


\subsection{Perceived value}

Barber et al. (2012) mentioned that customer perceived value was derived from Transaction Utility Theory proposed by Thaler, who argued that a consumer would consider the purchase based on the perceived value, i.e. the choice of perceived benefit and the perceived sacrifice of a consumer paying for a product. Dani-Elkebir (2011) indicated that a consumer would set the acceptable price range when purchasing a product; perceived value revealed a consumer considering the product price being lower than the acceptable price that the increasing perceived value would enhance the purchase intention. Kameswari and Rajyalakshmi (2012) regarded customer perceived value as the difference between perceived benefit and perceived sacrifice of a customer (including monetary and non-monetary costs) as well as the difference between profits and costs when a potential customer evaluated a provided object or other choices (Lin et al. 2011). O'Neill (2011) stated that requesting a customer was the most direct way to understand customer perceived value; in other words, perceived value was the subjective judgment of a customer that it needed to be understood from the viewpoint of a customer.

Referring to Wang et al. (2012), the following dimensions are proposed for customer perceived value.

(1) Product value. The value generated from product functions, characteristics, quality, variety, and patterns. It is the central content of customer demands as well as the primary factor in a customer purchasing a product. Under general conditions, it determines the total purchase value of a customer.

(2) Service value. Kameswari and Rajyalakshmi (2012) defined service value that perceived value was the overall evaluation of the product utility, based on what a consumer acquired and paid. Although there were differences between acquiring and paying, value was apparently the substitute in between.

(3) Experiential value. Barber et al. (2012) first proposed the customer value classification and regarded customer value as an experience not existing in the purchased products nor the selected brand or the possessed products, but completely from the consumption experience of a customer; a customer would acquire Rational Consumption Value and Experiential Consumption Value in the consumption process. 


\subsection{Research hypothesis, marketing strategy management, customer relationship management, and perceived value}

When a business engages in marketing strategy management, individual customers or consumers are usually regarded as the analysis unit. Individual customer files are established with information technology and database for providing customized products and services so as to search and establish long-term customer relationship management and acquire customer perceived value (Chen 2011). After practicing marketing strategy management, a business could enhance the customer relationship management and promote the customer perceived value (Eric et al. 2011). One-to-one marketing combines the idea of relationship marketing and the function of favorable database so that a business could provide personalized marketing mix and develop permanent customer relationship management to maximize the effectiveness of marketing strategy management. As previously mentioned, a business often applies confirmation, segmentation, interaction and customization proposed by Klaus and Maklan (2011) to the customer relationship management; the ideal result is to have individual customers receive distinct treatment, products, or services, enhance the perceived value, and reinforce the loyalty. A business should enhance the customer interaction and deliver excellent customer value; especially, when the business is combined with technologies, products and services conforming to different customer demands could be created through customer relationship management to reinforce the customer perceived value, assist the business in developing better customer relationship quality, and even enhance the customer commitment (Lliopoulos and Priporas 2011). According to above research, the following hypotheses are derived in this study.

H1: Marketing strategy management shows significant correlations with customer relationship management.

H2: Customer relationship management reveals remarkable correlations with perceived value.

In face of the rapidly changing environments, a business needs to understand the importance of marketing strategy management in the consumption environments, as the customer experiential cognition, service and perceived value appear to have great influence on attracting new customers and retaining existing customers (Yi et al. 2011). Klaus and Maklan (2011) found out perceived value as the mediator of marketing strategy management (price, place, promotion, and product) and purchase intention. O'Neill (2011) indicated that customer perceived value was a factor in differentiating and maintaining competitive advantages; 
therefore, a company had to provide customers with favorable marketing strategy management with more valuable products or services than other competitors so as to enhance the customer perceived value. According to above discussions, the following hypothesis is derived in this study.

H3: Marketing strategy management presents notable correlations with perceived value.

\section{RESEARCH METHODOLOGY}

\subsection{Method model}

The intrinsic quality of LISREL is often used as the assessment index, containing (1) SMC (square multiple correlation) indices related to individual manifest variables, i.e. R2 of manifest variables and latent variables, which should be larger than $0.5,(2)$ the reliability ( $\rho$ ) of latent variables, i.e. the Cronbach's $\alpha$ coefficient of the observed indices for latent variables, which should be larger than 0.6 , and (3) the average variance extracted of latent variables, by calculating the R2 sum of the manifest variables of a latent variable being divided by the number of manifest variables, revealing the percentage of latent variables being measured with manifest variables, which is better larger than 0.5 (Sharma 1996).

The goodness-of-fit test for LISREL could be measured with the overall model fit (i.e. the extrinsic quality of the model) and the intrinsic quality. That is, the common goodness-of-fit assessment indices for the overall model fit test cover (1) $\chi^{2}$ ratio (Chi-Square ratio), the difference between the actual theoretical model and the expected value, which is better less than 3, (2) the closer goodness-of-fit index (GFI) and adjusted goodness-of-fit index (AGFI) to 1, the better goodnessof-fit, (3) the root mean square residual (RMR) to reflect the square root of "fit residual variance/covariance mean", which is better less than 0.05 , and (4) the incremental fit index (IFI) above 0.9, revealing the excellent goodness-of-fit (Hair et al. 1998).

\subsection{Research sample and subject}

Suzhou Industrial Park, an important cooperation between China and Singapore, was approved by the State Council in February and started in May in 1994. The park covers $3.4 \%$ of the land in Suzhou City, where the $7.4 \%$ population creates about $15 \%$ economic aggregate, and is ranked on the top of "the most competi- 
tive zone in China" for years, the second of national development comprehensive evaluation of investment environment, and the top of national high-tech industrial development zone in Jiangsu Province. The manufacturers in Suzhou Industrial Park therefore are selected as the research subjects. The executives and employees of manufacturers in Suzhou Industrial Park are distributed 500 copies of questionnaire, and 367 valid copies are retrieved, with the retrieval rate $73 \%$.

\subsection{Reliability and validity test}

Validity refers to a measuring scale which could actually measure the degree of something which a researcher tends to measure. The common types of validity contain Content Validity for qualitative concept verification, Criterion Validity, which utilizes preset extrinsic criteria and the coefficient related to the test for the evaluation, and Construct Validity, used for evaluating the consistency of a measurement to other observable variables. Based on the past theories and considering the real situations of the research subjects, the questionnaire is designed to express the essence and represent the integrity so as to ensure the content validity. Besides, the final communality estimates of Factor Analysis are applied to test the construct validity of dimensions, and the validity appears in $0.816 \sim 0.875$, showing the favorable validity of the questionnaire.

Reliability refers to the consistency degree of repeatedly proceeding investigation or measurement on the same group of mother samples. Cronbach's $\alpha$ coefficient is often used for measuring the consistency among items in the same concept. In basic research, the reliability coefficient above 0.8 presents the scale with high reliability, while it is acceptable in exploratory research with the reliability reaching 0.7 . The Cronbach's $\alpha$ reliability coefficient in this study appears in $0.752 \sim 0.927$, conforming to the high reliability range of Cronbach's $\alpha$ coefficient between 0.7 and 0.98 proposed by Wortzel (1979).

\section{ANALYSIS OF THE EXPERIMENTAL RESULT}

\subsection{Test of model fit}

Maximum likelihood (ML) is utilized in this study, and the LISREL analysis reaches the convergence. The overall model fit indices for the extrinsic quality of the model show (1) $\chi^{2}$ ratio $=\chi^{2} /$ degree of freedom $=1.753$, less than $3,(2)$ goodness-of-fit index GFI $=0.96$, larger than 0.9 and adjusted goodness-of-fit index AGFI $=0.88$, larger than $0.8,(3)$ root mean square residual $\mathrm{RMR}=0.023$, 
less than 0.05 , and (4) incremental fit index 0.93 , larger than 0.9. Overall speaking, the indices for the overall model fit pass the test, completely reflecting the favorable extrinsic quality of LISREL.

In regard to the test of the intrinsic quality, SMC of manifest variables being larger than 0.5 (Tables 1 and 2) reveals the favorable measuring indices for latent variables. Furthermore, the reliability of latent variables, including marketing strategy management, customer relationship management, and perceived value is larger than 0.6 , and the average variance extracted is larger than 0.5 (Table 3), which apparently conform to the test of the intrinsic quality of the model.

Table 1. SMC of variables to dimension

\begin{tabular}{c|c|c|c|c|c|c}
\hline \multicolumn{7}{c}{ Marketing strategy management } \\
\hline Product & Price & Place & Promotion & Participant & Process & $\begin{array}{c}\text { Physical } \\
\text { evidence }\end{array}$ \\
\hline 0.71 & 0.78 & 0.80 & 0.83 & 0.85 & 0.89 & 0.91 \\
\hline
\end{tabular}

Table 2. SMC of variables to dimensions

\begin{tabular}{c|c|c|c|c|c}
\hline \multicolumn{2}{c|}{ Customer relationship management } & \multicolumn{3}{c}{ Perceived value } \\
\hline $\begin{array}{c}\text { Customer } \\
\text { acquisition }\end{array}$ & $\begin{array}{c}\text { Customer } \\
\text { reinforcement }\end{array}$ & $\begin{array}{c}\text { Customer } \\
\text { bonding }\end{array}$ & Product value & Service value & $\begin{array}{c}\text { Experiential } \\
\text { value }\end{array}$ \\
\hline 0.63 & 0.68 & 0.75 & 0.66 & 0.72 & 0.77 \\
\hline
\end{tabular}

Table 3. Reliability and average variance extracted of variables

\begin{tabular}{c|c|c|c}
\hline Item & $\begin{array}{c}\text { Marketing strategy } \\
\text { management }\end{array}$ & $\begin{array}{c}\text { Customer relationship } \\
\text { management }\end{array}$ & Perceived value \\
\hline Reliability & 0.752 & 0.845 & 0.927 \\
\hline $\begin{array}{c}\text { Average variance } \\
\text { extracted }\end{array}$ & 0.73 & 0.82 & 0.89 \\
\hline
\end{tabular}

\subsection{Test of path relationship}

When product, customer acquisition, and product value of latent variables are selected as the reference indicator with the constant value 1 (Bollen and Long 1993), the relationship estimates between other dimensions and variables are significant, see Figure 1. That is, price $=1.10$ and place $=1.23$ reveal better explanation than product; customer bonding $=1.08$ presents better explanation than customer acquisition; and perceived service value $=1.05$ is relatively higher than perceived product value. The hypothesis verification results are shown in Table 3. 


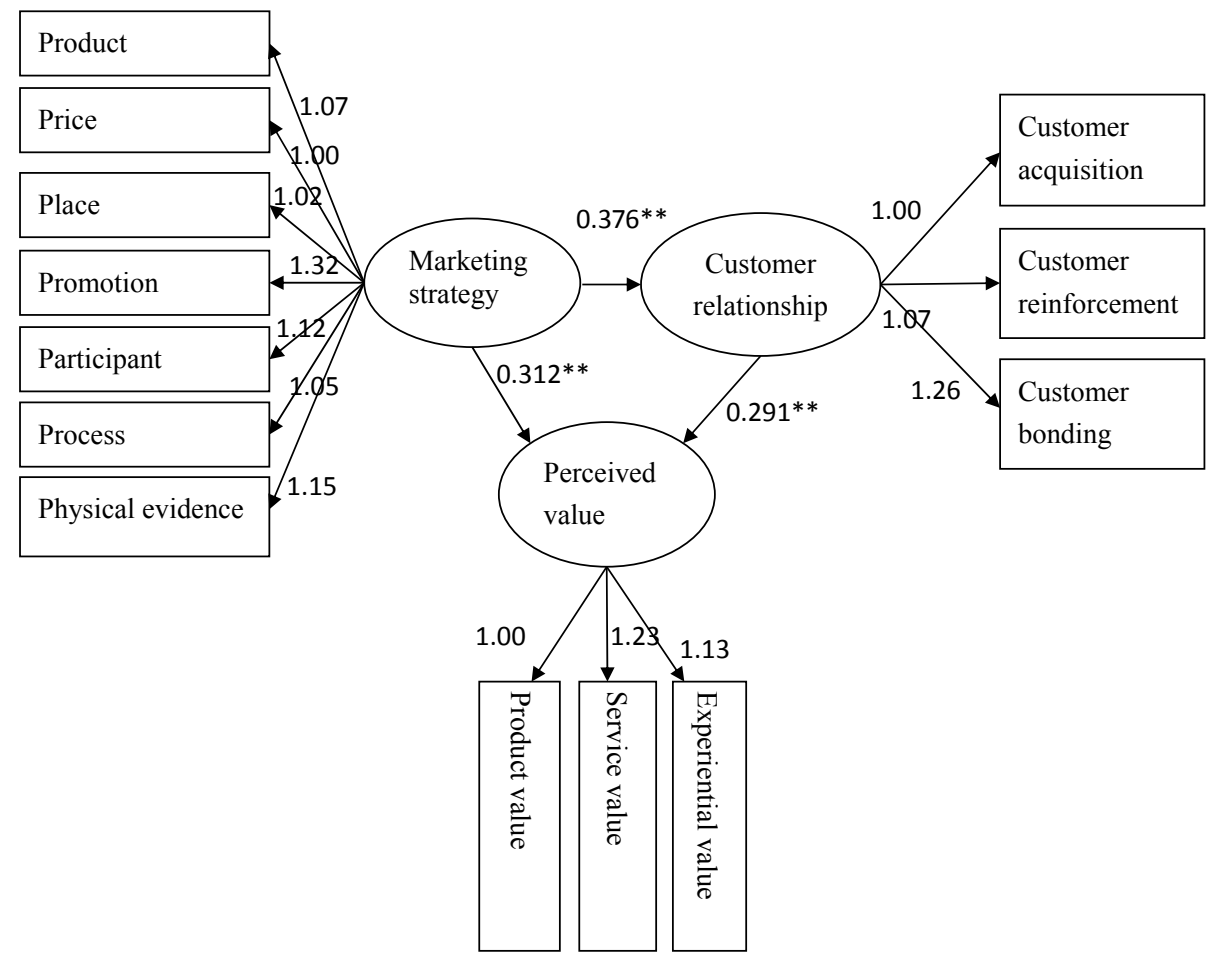

Figure 1. Causal path diagram

Table 4. Hypothesis verification

\begin{tabular}{l|c|c|c|c}
\hline Hypothesis & Correlation & $\begin{array}{c}\text { Experimental } \\
\text { result }\end{array}$ & $\mathrm{P}$ & Result \\
\hline $\mathrm{H} 1$ & + & 0.376 & 0.00 & supported \\
\hline $\mathrm{H} 2$ & + & 0.291 & 0.00 & supported \\
\hline $\mathrm{H} 3$ & + & 0.312 & 0.00 & supported \\
\hline
\end{tabular}

\section{CONCLUSION}

The research findings show the significantly positive effects of marketing strategy management on customer relationship management that the more emphasis on the operation of marketing strategies shows the better performance on customer relationship management. The remarkably positive effects of customer relationship management on organizational performance reveal that the more emphasis on the 
promotion of customer relationship management would result in better perceived value. The research results present certain contributions to marketing strategy management and customer relationship management. Perceived value is the subjective perception of a consumer towards the products of a company, which is considered general and comprehensive. Besides, the perception difference among consumers is caused by the subjective preference that a service provider, i.e. the business, could merely enhance the services to the ordinarily agreed level, but could not satisfy individual consumer requests. Nonetheless, customer relationship management could make up such a fault. More interaction and personalized services could be generated through marketing strategy management. Based on the favorable service level and aiming at individual consumer preference and demands, customized services could be created to enhance the perceived consumption experiences. This study aims to discuss the factor of customer relationship management in the promotion of consumer loyalty under favorable perceived value.

\section{SUGGESTION}

Summing up the results and findings, the following practical suggestions are proposed in this study.

1. A business should stress on and enhance the product quality and competitive prices. A business should provide customers with reliable product quality and rapidly pay attention to the service attitudes and quality as well as offer customers with reasonable prices which allow customers perceiving the economic benefits and being willing to pay the prices in the fiercely competitive markets. A business is also suggested to meet the changeable and diverse consumer styles, pay attention to product package and quality, regularly adjust the product variety and choices according to the marketing strategy management, and formulate more competitive price strategies in order to enhance the operation and management competitive capabilities.

2. Business services should stress on customer relationship management. Broadly speaking, customer relationship management could be the interaction between customers and businesses. In practice, it involves in the application of customer data to effectively promote the customer services and enhance the interactive relationship between a business and the customers. Customer relationship management not only could enhance the interactive relationship between a business and the customers but also collect customer data through such relationship. Favorable customer relationship management could reduce the costs for developing potential customers and new customers, enhance business efficiency, and reduce unnecessary resource and cost waste. Moreover, 
good customer relationship management could directly and indirectly achieve the function and purpose of work-of-mouth marketing.

3. A business should emphasize customer interaction and customized services. The collected customer data contain consumer responses to the marketing activities, consumer consumption habits, segmented services for different customer attributes, increasing contact with consumers, and enhancement of customized services. The data analyzes are generated from the interaction between customers and the business that analyzing customer data could effectively master the characteristics to become the reference for operation and performance evaluation. A business therefore is suggested to reinforce the customer perceived value, establish and accumulate good consumption experiences of consumers, and promote the customer loyalty for the oral spreading and actively sharing recommendations and repurchase behaviors so as to achieve the operation objectives and service performance, and create sustainable value.

\section{ACKNOWLEDGEMENTS}

1. Project No.12XGL020 supported by the National Social Science Foundation of China

2. Project No.CQDXWL-2013-Z004,CDJSK 11016 and CDJRC10010012 supported

by the Fundamental Research Funds for the Central Universities

3. Project No.70902030, 71372137 supported by the National Nature Science Foundation of China

\section{REFERENCES}

Amila, A.P. and Aruna, S. (2012). Job satisfaction and job performance of the sailors in rapid action boat squadron of Sri Lanka navy. Sri Lankan Journal of Human Resource Management, 3(1), $49-57$.

Ayodele, J.B. and Olorunsola, E.O. (2012). The relationship between job satisfaction and performance of administrative staff in South West Nigeria Universities. Department of educational foundations and management, institute of education, University of Ado-Ekiti, Nigeria, Kamla-Raj, J SocSci, 30(3), 313-316.

Barber, N., Pei-Jou, K., Bishop, M. and Goodman, J.R. (2012). Measuring psychographics to assess purchase intention and willingness to pay. Journal of Consumer Marketing, 29(4), 280-292.

Bollen, K.A. and Long, J.S. (eds.) (1993). Testing Structural Equation Models. U.K.: Sage Publications.

Chen, M.H. (2011). The response of hotel performance to international tourism development and crisis events. International Journal of Hospitality Management, 30(1), 200-212. 
Chiu, W.Y., Lee, Y.D. and Lin, T.Y. (2011). Innovative services in fitness clubs: personal trainer competency needs analysis. The International Journal of Organizational Innovation, 3(3), 317-328.

Dani-Elkebir, M.M. (2011). Situational factors influencing impulse buying behavior of Algerian consumer. Romanian Journal of Marketing, 6(2), 52-59.

Eric, Q.R. Mitch, C.B. Sebastian, R. and Petra, N.A. (2011). Innovation as a knowledge-based outcome. Journal of Knowledge Management, 15(6), 928-947.

Graa, A. and Dani-el Kebir, M. (2012). Application of stimulus \& response model to impulse buying behavior of Algerian consumers. Serbian Journal of Management, 7(1), 53-64.

Green, T. and Peloza, J. (2011). How does corporate social responsibility create value for consumers? Journal of Consumer Marketing, 28(1), 48-56.

Hair, J.F., Anderson, R., Tatham, R.L. and Black, W.C. (1998). Multivariate Data Analysis. N. J.: Prentice Hall Inc., 5th ed.

Kameswari, A.V. and Rajyalakshmi, N. (2012). Role of internal marketing in job satisfaction of employees in State Bank of India. Andhra University, Visakhapatnam, January 1-4, Ninth AIMS International Conference on Management.

Klaus, Ph. and Maklan, S. (2011). Bridging the gap for destination extreme sports - a model of sports tourism customer experience. Journal of Marketing Management, 27(13-14), 1341-1365.

Klaus, Ph. and Maklan, S. (2012). EXQ: a multiple-item scale for assessing service experience. Journal of Service Management, 23(1), 5-33.

Lee, S.K. and Jang, S. (2011). Foreign exchange exposure of US tourism-related firms. Tourism Management, 32(4), 934-948.

Lin, L., Horng, J.S., Chen, Y.C. and Tsai, C.Y. (2011). Factors affecting hotel human resource demand in Taiwan. International Journal of Hospitality Management, 30(2), 312-318.

Lliopoulos, E. and Priporas, C.V. (2011). The effect of internal marketing on job satisfaction in health services: a pilot study in public hospitals in Northern Greece. BMC Health Services Research, 11, 261.

López-Gamero, M.D., Molina-Azorín, J.F. and Claver-Cortes, E. (2011). The relationship between managers' environmental perceptions, environmental management and firm performance in Spanish hotels: a whole framework. International Journal of Tourism Research, 13(2), 141163.

Ogunnaike, O.O., Oyeniyi, O. and Adenike, A.A. (2012). Internal marketing practices and job satisfaction: Evidence from a Nigerian University Setting. BRAND, Broad Research in Accounting, Negotiation, and Distribution, ISSN 2067-8177, 3 (3), 18-30.

O'Neill, J.W. (2011). Hotel occupancy: Is the three-year stabilization assumption justified? Cornell Hospitality Quarterly, 52(2), 176-180.

Sharma, S. (1996). Applied Multivariate Techniques. N. Y.: John Wiley \& Sons, Inc.

Tseng, C. (2011). Cultural and Creative Industry 2012. TIER Industry Report, Cultural \& Creative Industry, 1-7.

Wang, C.H., Chen, K.Y. and Chen, S.C. (2012). Total quality management, market orientation and hotel performance: The moderating effects of external environmental factors. International Journal of Hospitality Management, 31(1), 119-129.

Wortzel, R. (1979). New life style determinants of women's food shopping behavior. Journal of Marketing, 43, 28-29.

$\mathrm{Xu}, \mathrm{A}$. and Shieh, C.J. (2014). Effects of marketing ethics on customer satisfaction in tourism industry. Acta Oeconomica, 64(Supplement 2), 243-255.

Yi, Y., Nataraajan, R. and Gong, T. (2011). Customer participation and citizenship behavioral influences on employee performance, satisfaction, commitment, and turnover intention. Journal of Business Research, 64, 87-95. 